ВЕСТНИК БУРЯТСКОГО ГОСУДАРСТВЕННОГО УНИВЕРСИТЕТА.

Научная статья

УДК 94(571.54)

DOI: $10.18101 / 2305-753 X-2021-4-18-23$

\title{
НЕИЗВЕСТНОЕ ОПИСАНИЕ ТРОИЦКОСАВСКА-КЯХТЫ
}

\author{
(C) Паликова Татьяна Вадимовна \\ доктор исторических наук, профессор, \\ Бурятский государственный университет имени Доржи Банзарова \\ Россия, 670000, г. Улан-Удэ, ул. Ранжурова, 6 \\ nnet2861@gmail.com
}

\begin{abstract}
Аннотация. Публикация посвящена неизвестному описанию Троицкосавска-Кяхты и расположенного рядом Кяхтинского маймачена, содержащемуся в письме к сестре Екатерины Александровны Сергеевой во время переезда в город для продолжения обучения в гимназии, сохранившемся в Государственном архиве Республики Бурятия в именном фонде М. В. и Е. А. Танских. В ходе изучения документа была проведена уточняющая атрибуция письма, в частности установлена точная дата его написания и даны комментарии, в том числе с привлечением некоторых наиболее известных фрагментов текстов, посвященных этому городу. Следует сказать, что данное описание содержит некоторые уточнения и передает индивидуальноэмоциональное восприятие на город.
\end{abstract}

Ключевые слова: эпистолярии, Троицкосавск, Кяхта, маймачен, неизвестное описание, начало XX в.

\section{Для цитирования}

Паликова T. В. Неизвестное описание Троицкосавска-Кяхты // Вестник Бурятского государственного университета. Гуманитарные исследования Внутренней Азии. 2021. Вып. 4. С. 18-23.

Сегодня в арсенале исследователей истории Забайкалья и Дальнего Востока скопилось немало изображений Троицкосавска-Кяхты. Члены научных экспедиций, участники православных миссий, путешественники из Центральной России, военные, направлявшиеся в Монголию и Китай на протяжении нескольких столетий, оставили свои описания города, расположенного на границе, встречавшего и провожавшего их.

В этот значительный по объему набор отечественных и зарубежных травелогов можно включить еще одно описание города 13-летней девочкой, впервые покинувшей родной дом, чтобы продолжить обучение в Троицкосавске.

Екатерина Александровна Сергеева, в замужестве Танская, родилась в 1885 г. в дворянской семье кадрового офицера, сосланного в Забайкалье. Окончив Верхнеудинскую женскую 3-х классную прогимназию, Екатерина Сергеева с 1898 г. продолжила свое обучение в Троицкосавской женской гимназии им. графа Н. Н. Муравьева-Амурского. Собственное полное среднее женское учебное заведение в Верхнеудинске было открыто только в 1906 г., а прогимназия, хотя и считалась средним образовательным заведением, предполагала лишь четырехлетнее обучение, поэтому девушки для получения среднего образования вынуждены были переезжать в Иркутск, в Троицкосавск или в Читу (с 1893 г.). 
Предлагаемое читателю описание содержится в письме к сестре Марии Александровне. Письмо представляет собой 8 страничек почтовой бумаги, исписанных черными чернилами детским неровным почерком. Письмо, сохранившееся в именном фонде М. В. и Е. А. Танских [Р-1778], не имеет начала, атрибутировано 1902 г. и адресовано М. А. Верхотуровой, с чем нельзя согласиться. Вопервых, потому что Е. Сергеева проживала у Е. С. Ткаченко до 1899 г. и это единственное во всей переписке с сестрой описание города и пути до него, а, вовторых, Мария Александровна, как следует из ее письма, вышла замуж только в 1902 г. ${ }^{1}$, поэтому Екатерина адресовала письма еще Марии Сергеевой.

События, описанные в письме, произошли в августе 1898 г., о чем свидетельствует упоминание «престола» - одного из двунадесятых непереходящих праздников православной церкви, посвященного Успенью Пресвятой Богородицы, отмечавшегося 15 августа (по ст. ст.): «14го я была у всеночной, там 15го престол. К обедне в Успенье не ходила был дождь до полдня» ${ }^{2}$. Поэтому путешествие, предпринятое Е. Сергеевой и Е.С. Ткаченко, состоялось 9-12 августа, а письмо, следовательно, написано не позднее конца августа - начала сентября 1898 г.

Следует обратить внимание на предварительную подготовку условий обучения дочерей в других городах, особенно, если при учебном заведении отсутствовал пансион (общежитие). Трудно сказать, была ли семья Сергеевой знакома с Екатериной Софроновной Ткаченко, но эта женщина не только приютила гимназистку (хотя сама снимала квартиру), но и привезла ее в Троицкосавск, познакомив с городом.

Расстояние от Верхнеудинска до Троицкосавска, в котором будет учиться Е. Сергеева составляло 240 верст, поэтому путешествие растянулось на три дня. Видимо, у Е. С. Ткаченко были свои планы, т. к. часть пути заняла поездка на пароходе до Селенгинска, где их «встретил батюшка брат самой Ткаченко такой же толстый как батюшка отеи Иоан Писарев», а затем - на лошадях в Троицкосавск ${ }^{3}$.

Описание города публикуется с сохранением орфографии оригинала.

«Троиикосавск очень красивый город, везде бульвары (около тротуаров насажены березки), везде садики. Городской сад очень красивый густой как лес прямо заблудиться можно. ... потом еще 3 больших сада. Один кругом Собора, другой кругом Никольской церкви, а третий каких то купџов. Здесь три церкви Никольская, Собор и Успенская, которая стоит на кладбище.

Новых зданий масса. Дома большею частею деревянные крашенныя. Реальное училище большое каменное здание $2 x$ этажное. Возле него Женская гимназия стоят на большой улице. ... От Троичкосавска до Кяхты 4 1² версты. Кяхта большой порядочный город. Дома все красивые хотя деревянныя, в Кяхте у купечества свой клуб, там 2 черкви в одну мы заходили во время всеночной. Церковь очень красивая везде хрустальные колонны, везде серебро и шелк. На полах персидские ковры, на аналоях шелковые накидки, иконы, писанные масляными крас-

\footnotetext{
${ }^{1}$ ГАРБ. Ф. Р-1778. ОП. 1. Д. 131. Л. 86.

${ }^{2}$ ГАРБ. Ф. Р-1778. ОП. 1. Д. 118. Л. 119.

${ }^{3}$ Там же.
} 
ками, украшения иконостаса серебрянныя. Служил дъякон голос я тебе, Маня, выразить не могу, это будто бык.

На кладбище несколько памятников: 1 мраморный аналой и на нем лежит Евангелие и Крест. Потом Немчинова склеп в виде памятника, с одной стороны стеклянная двериа, там весит распятие и еще две иконы и горит неугасимая лампада. На этом склепе весит венок ... в оградке по углам всевозможныя иветыл. Потом из Кяхты пошли в Маймачену. Маймачена от Кяхты в 20 саженях. Стены в Маймачене сделаны из глины с соломой и дома из того же. Ворота деревянные над воротами изогнутые крыши и на них посажены разные драконы. Когда зайдешь в ворота перед твоими глазами разстелается картина с одной и с другой стороны, т.е. по бокам жилье помещения, в задней стене калитки ..., пол во дворе деревянный, чистый. У китайцев богатых опрятность и чистота, посередине двора столик на нем стоят домашния иветы. Но вот что меня там сильно заинтересовало, то это олеандра (в небольшой кадушке). Прямой ствол и вдруг развернулась как веер и вся в иветах, однако больше полтысячи иветов на ней. Улицы узкие и грязные. В Маймачине живет ихний генерал Зергучей, у него во дворе стоят ихние Боги. Какие то львы с разинутыми пастями и там лежит по шару. Глаза по чайной чашке желтые, еще какие то кони, но самое интересное столбы. По середине двора Зергучея стоят два каменных столба прегромадныя вышиной саженей 15, как будто бы смочены ... в красную краску, на верху золотые головки почти что на самом верху приделан блок и к нему привязана толстая веревка и конщы спущены вниз. Говорят, на этих столбах казнят китайщев, не вдалеке стоят 2 деревянных столба. Около этих столбов стоят в четверти 1 1/2 тумбочки, покрытые как будто шляпой ...с колпочками наверху с шитечкой» 1 .

Троицкосавск в последней четверти XIX в. в административном отношении включал в себя город и две слободы: торговую Кяхту и Усть-Кяхту. У девочкиподростка, приехавшей из Верхнеудинска, города значительно уступавшего по размерам (не более 5,5 тыс жителей) и благоустройству (единственный скверик на весь город), Троицкосавск вызвал восхищение, как и его торговая слобода. Кстати сказать, город неизменно производил благоприятное впечатление на всех побывавших в нем. Так, В. Обручев писал: «Городок был небольшой (8 mысс. населения), но хорошо обстроенный и зажиточный; дома частью двухэтажные, иногда каменные, улищы глубокопесчаные, но с деревянными тротуарами; каменный собор и две иеркви, большой гостиный двор, общественный сад» [4]. Не обошли стороной путешественники и Кяхту, восприятие которой почти не отличается от восприятия Е. Сергеевой. Почти теми же словами описывали слободу и Д. Стахеев в середине 60-х гг. XIX в.: «Первое, что удивляло каждого, приезжавшего в Кяхту, это необыкновенная чистота и как-будто новизна построек. Дома, крыши, заборы казались только-что выкрашенныли» [6], и Г. М. Осокин в начале XX в.: «В общем Кяхта по наружному виду оставляет приятное впечатление довольства, чистоты, чему много способствует и местоположение ее с широкой, ровной улицей, прекрасным бульваром, общественным и част-

${ }^{1}$ ГАРБ. Ф. Р-1778. Оп. 1. Д. 118. Л. 120-122. 
ными садами и чистым веселым видом, в большинстве, бельх, высоких построек» [3, c. 22].

И, конечно, особо обращалось внимание на ее знаменитую достопримечательность - Воскресенский собор, который Сергеева описывает, но не называет, считавшийся вторым после Исаакиевского собора храмом в империи. «Двойные двери перед алтарем сделаны из чистого серебра и, как говорят, весят две тысячи фунтов «эвердьюпойс». Кроме этих дверей я видел, как мне кажется, около тонны серебра в разнообразной церковной утвари. Церковь была построена на деньги кяхтинских купџов» [5], «в 20х годах спечиально выписанными итальянизами» [2].

Перечисляя церкви Троицкосавска, Екатерина под «Собором» подразумевает Троицкий собор, построенный в 1812-1817 гг. в классическом стиле, долгие годы считавшийся одним из крупнейших храмов в Забайкалье, известный своей чудотворной иконой Божией матери «Сподручницей грешных», о молитве перед которой Е. Сергеева не единожды упоминала в своих письмах сестре. Говоря о Никольской церкви, автор эпистолярия имеет в виду Покровскую церковь, построенную в 1860-х на месте разобранной деревянной Николаевской, в память о которой был освящен один из приделов, поэтому Покровский храм имел и другое название Покровско-Никольский.

Сообщая сестре о памятниках на кладбище, Е. Сергеева имела ввиду кладбище при Успенской церкви, построенной в 1884-1888 гг. купцом 1 гильдии, миллионером Я. А. Немчиновым, где нашли упокоение его жена, дочери и другие родственники.

Однако, если судить по объему текста, на девочку большее впечатление произвел соседний торговый городок - китайский Маймачен, прежде всего необычностью своего внешнего вида.

Это придавало Кяхте исключительное своеобразие, которое не мог обойти ни один «посетитель» Троицкосавска. И опять текст Е. Сергеевой перекликается с текстом Д. Стахеева: «...фигурные китайские крыши соседнего города Маймачина, высокия башни ворот, с раскрашенными драконами...» и В. Обручева, который упоминает красивый храм Конфуция и фигуры богов и героев вокруг него [2; 4].

Судя по содержанию, девочку привлек олеандр (использует название в женском роде). Можно говорить о том, что это средиземноморское растение было распространено как комнатный цветок и девочка и ее сестра были с ним знакомы. Скорее всего, необычность заключалась в прямом стволе кустового растения.

Второй момент, обративший ее внимание, «несколько столбов с золочеными на верху их шарами» применялись «для обозначения места, где живет китайский начальник города (дзаргучей)» [4]. Использование искаженного «зергучей» неслучайно, либо так было произнесено это слово сопровождавшим ее, либо так было услышано ей. Скорее всего, интерес вызвало сообщение о казнях. Нами не было найдено описания практик этого действия в Кяхтинском маймачене, как и более подробного описания столбов так заинтересовавших ее, но, учитывая, упоминания о подобном наказании в маймачинах Северной Монголии русскими путешественниками $[1$, с. 35,38$]$, сообщение не лишено основания. 
В завершение скажем, что Екатерина Александровна еще несколько раз сообщала сестре о посещении в 1900 г. Маймачена на «фонарный день» и театральное представление с очень кратким описанием двора «зергучея»: «Двор загорожен со всех сторон постройками от которых опять отделяется решеткой оградкой окрашенной в пестро яркие ивета, во дворике его драконы ..., и тут каменныя собачки, и, львы и т.п. Прямо против входа построена порядочной вышины возвышение с крышей (это сиена). Сцена к публике открыта без всякого занавеса. На сиене стоят столики очень низкия и 2 трона. В одном углу сидят китайские музыканты с медными тарелочками, китайской скрипкой и трещетками, под этот акомпонимент поют и разговаривают» и собственно представления (содержание пьесы) ${ }^{1}$ и в 1901 г. — о нравах кяхтинских купцов: «Что волнует и занимает наших купиов? Лошади и охота. Остальное, кажется, для них и не существует. Как были они 25 лет тому назад, так и остались навеки вечныя. И железная дорога, и поездки загранииу и в Россию, абсолютно ничего нового не внесли в их жизнь. По-прежснему охота и лошади единственное святило и цель их жизни. Газеты и те для них почти не существуют. И живут без всяких духовных интересов. И находят, что их жизнь хороша» ${ }^{2}$.

Наконец, и в описании 1898 г., и в описании 1900 г. перечисляются фигуры мифических животных, каждое из которых несет в себе глубокий символизм, связанный с буддизмом: дракон, лев (снежный лев), собака (Собака Фу/собаколев) и конь - охранители и защитники Будды - символы просветления, олицетворения Будды, верности и свободы.

Таким образом, письмо как элемент личной переписки становится важным источником отражения эпохи, фиксируя события и факты, увиденные непосредственно автором. Не рассчитанное на публичное освещение, оно несет фактическую информацию, уточняя или расширяя уже известные факты, изъятые историками из других источников. Будучи субъективно окрашенным, отразив авторские эмоции восприятия Троицкосавска-Кяхты - маймачена, оно коррелирует с другими описаниями, создавая реальную картину отражаемого временного отрезка.

Литература

1. Намсараева С. Б. Миграции во Внутренней Азии цинского периода: диаспоры «контактной зоны» Кяхта-Маймачен // Вестник Бурятского государственного университета. Гуманитарные исследования Внутренней Азии. 2013. № 1. С. 21-46. Текст: непосредственный.

2. Обручев В. От Кяхты до Кульджи. URL: http://sibirica.su/sunduk/ot-kyachti-dokuldzhi (дата обращения: 15.10.2021). Текст: электронный.

3. Осокин Г. М. На границе Монголии. Очерки и материалы к этнографии ЮгоЗападного Забайкалья. Санкт-Петербург: Типография А. С. Суворина, 1906. 304 с. Текст: непосредственный.

4. Стахеев Д. Очерк 8. Кяхта // Живописная Россия. URL: http://sibirica.su/sunduk/ kyachta/stranitsa-31 (дата обращения: 15.10.2021). Текст: электронный.

${ }^{1}$ ГАРБ. Ф. Р-1778. Оп. 1. Д. 118. Л. 53-54.

${ }^{2}$ ГАРБ. Ф. Р-1778. Оп. 1. Д. 118. Л. 28. 
T. В. Паликова. Неизвестное описание Троицкосавска-Кяхты

5. Эйвери М. Чайный путь. URL: http://www.pribaikal.ru/obl-events/article/20211.html (дата обращения: 15.10.2021). Текст: электронный.

Статья поступила в редакцию 12.11.2021; одобрена после рецензирования 03.12.2021; принята к публикации 17.12.2021.

\section{UNKNOWN DESCRIPTION \\ OF TROITSKOSAVSK-KYAKHTA}

Tatyana V. Palikova

Dr. Sci. (History), Prof. of World and Russian History Department,

Dorzhi Banzarov Buryat State University

6 Ranzhurova St., Ulan-Ude 670000, Russia

nnet2861@gmail.com

Abstract. The article is devoted to an unknown description of Troitskosavsk-Kyakhta and Maymachen contained in a letter to Ekaterina Alexandrovna Sergeeva's sister during her moving to the city for continue her studies at the gymnasium. These documents are preserved in the State Archive of the Republic of Buryatia in the named fund of M. V. and E. A. Tanskikh. During the study of the documents, a clarifying attribution of the letter was carried out, in particular, the exact date of its writing was established and comments were given, including involving some of the most famous fragments of texts dedicated to this city. This description contains some clarifications and conveys an individual emotional perception of the city.

Keywords: epistolaries, Troitskosavsk, Kyakhta, maymachen, unknown description, early twentieth century.

For citation

Palikova T. V. Unknown Description of Troitskosavsk-Kyakhta. Bulletin of Buryat State University. Humanities Research of Inner Asia. 2021; 4: 18-23 (In Russ.).

The article was submitted 12.11.2021; approved after reviewing 03.12.2021; accepted for publication 17.12.2021. 